\title{
EDITORIAL
}

\section{Terrorism, fundamentalism, and compartmentalism}

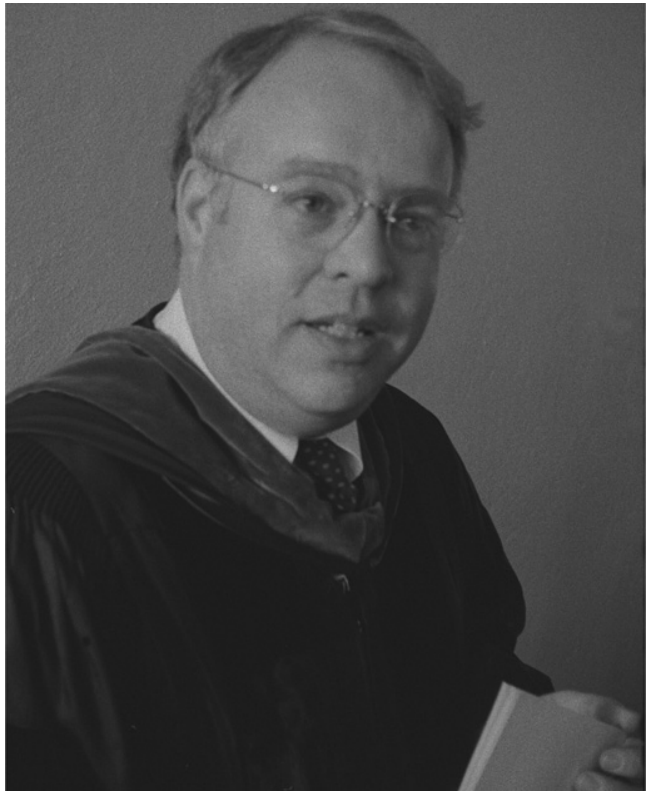

Timothy R.B. Johnson, MD

Editor-in-Chief, IJGO

As former FIGO President Mahmoud Fathalla once said: "Women are not dying because of diseases we cannot treat. They are dying because societies have yet to make the decision that their lives are worth saving" [1]. In addition to this tragic lack of attention and concern, I have come to believe that there are forces working against women's health globally that could be characterized in many ways, but which can be summarized under 3 categories: terrorism, fundamentalism, and compartmentalism.

Just weeks ago in Pakistan, 15-year-old Malala Yousafzai-a young advocate for women's and girls' right to education-was shot in front of her classmates on a school bus by persons identifying themselves as the Taliban who objected to her advocacy for the rights of girls and women. Terrorism plays out across the world as rape, genocidal rape, and organized rape. The death of a young medical student brutally raped and beaten on a bus in Delhi becomes emblematic of a national problem [2], and armed groups rape and plunder in Syria and elsewhere. Our colleague obstetrician-gynecologist, Doctor Denis Mukwege escaped a recent assassination attempt targeted at him for speaking out and acting against organized systematic rape [3]: "The women victims of sexual violence expect greater political determination at the regional, national, and international levels" [4].
Terrorism also manifests as bride burning, dowry deaths, and widespread domestic and interpersonal violence. Terrorism was a keynote plan of the Taliban and their initial take over in Afghanistan in 1996 when they closed girls' schools and refused to allow women to work. In 2006, despite an American invasion and a new government, terrorism remained rampant as the Taliban shot Safia Amajan, a 65 -year-old former school teacher and high-school principal who was the Chief of Women's Affairs in Kandahar Province [5]. Girls are afraid to walk to school for fear that acid will be thrown in their faces from attackers on passing motorcycles [6]. Clearly, this terrorism must have a chilling effect on women, girls, and their families, and as FIGO continues to advocate for women and girls we must ensure that we do not place these galvanized and activist girls and women in harm's way. In the USA, the murders of obstetriciangynecologist Doctor Barnett Slepian in his home in 1998 [7] and of Doctor George Tiller in his church in Wichita, Kansas, in 2009 [8] demonstrate that terrorism crosses all boundaries and borders in its attempt to suppress and stifle women's sexual and reproductive rights. Terrorism cannot be tolerated and we must not allow its chilling effect to blunt our activism and advocacy.

Fundamentalism can manifest as religious fundamentalism or antiscientific fundamentalism. Religious fundamentalism speaks against access to contraception and abortion where it is legal. Fundamentalists speak against the use of condoms for the prevention and transmission of HIV/AIDS, even among married heterosexual partners and at-risk same sex partners, and they resist $\mathrm{ABC}$ (abstinence, be faithful, and use condoms) education. They work to prevent HPV immunization, which has the potential to save the lives of millions of women from cervical cancer. Emergency contraception is contested for women of all ages. In Cairo, fundamentalist cleric Yusuf El-Badry has challenged recently enacted Egyptian laws banning female genital mutilation, claiming "religious" rights to the procedure despite condemnation of the practice by the most respected and highest Islamist authorities [9].

Antiscientific fundamentalism may be even more problematic. HIV/ AIDS gives a clear example of scientific denial that has harmed women and their children. Former South African Minister of Health, Doctor Manto Tshabalala-Msimang, stated repeatedly that HIV was not the result of the AIDS virus and advocated a special diet including garlic and beetroot. She prevented the dissemination of antiretroviral therapy to treat the disease and to prevent woman-to-child transmission leading to hundreds of thousands of deaths [10]. With the election of President Zuma and appointment of a new Minister of Health, national distribution of antiretroviral therapy led to prompt and significant reduction of neonatal HIV and widespread access to therapy for all.

We know from many studies in many countries that restrictive abortion legislation neither increases the number of births nor reduces the number of abortions; instead, it increases the number of women who 
die from unsafe abortion and increases the number of long-term complications of unsafe abortion, including chronic infections, pelvic pain, and infertility.

Antiscientific fundamentalism has also delayed the implementation of projects to prevent and reverse global warming [11], delayed research using human embryonic stem cells, provided misinformation about the alleged risks to adolescents of the HPV vaccine, and recently introduced ridiculous and politically lethal concepts of rape including "legitimate rape" that provide a barrier to pregnancy [12,13].

Women's health care it too often compartmentalized. A prime example is initial mother-to-child transmission programs (MTCTP), which provided pregnant women who were found to be HIV positive, after voluntary counseling and testing, with antiretroviral therapy until delivery of a healthy child. Early programs stopped therapy to these women after delivery since the funding and funders targeted healthy newborns and not the healthy woman across her lifespan. These programs simply utilized women as an intermediary to prevent neonatal HIV. This has been remedied now with the institution of WTCTP-WOMAN-to-child transmission programs-that guarantee HIV-positive women lifelong access. Too often, the form of women's health programs follows funding. Women who receive pregnancy and postpartum delivery care are sent to another site for family planning, and yet another site for their cervical cancer screening. Little thought is given to the burdens of travel and time. There is no holistic view or comprehensive goal. Funders of maternity clinics and hospitals may not be interested in family planning (fundamentalism again?), and family planning agencies may not be interested in pregnancy care. Abortion care is often stigmatized and marginalized; postabortion care is fragmented or does not exist. HPV immunization and cervical cancer screening programs may develop separately from family planning or pregnancy programs, although the reproductive basics are the same, and women do not see themselves as a collection of reproductive organs and do not make these distinctions in their lived lives.

Clinical care by obstetrician-gynecologists is compartmentalized when we fail to screen for age-specific medical risks and conditions and when we fail to screen, diagnose, treat, or refer our patients for mental health problems or chronic medical conditions.

If FIGO and its constituent societies and their member obstetriciangynecologists-meaning us-are truly committed to what is best for women's health then we must acknowledge the global threats of terrorism, fundamentalism, and compartmentalism. We need to work aggressively and tirelessly as clinicians and also as advocates and activists for women's health on the national and international stage. In this editorial I have "sung" the names of some of my heroes who have done that. If we want our patients, and their daughters, and our daughters, to take the risks of being on that stage, then we must help build it and stand on it to welcome and support them.

\section{References}

[1] Fathalla MF. Human rights aspects of safe motherhood. Best Pract Res Clin Obstet Gynaecol 2006;20(3):409-19.

[2] Shah Singh H., Kapur M. New Delhi rape exposes the perils of being a woman in India. CNN website. http://www.cnn.com/2012/12/21/world/asia/india-rape-danger/ index.html. Accessed January 22, 2013.

[3] Kron J. Noted women's rights activist in Congo eludes group of gunmen. New York Times. October 26, 2012. http://www.nytimes.com/2012/10/27/world/africa/humanrights-doctor-in-congo-eludes-gunmen.html. Accessed January 22, 2012.

[4] Mukwege D. No more! Organized rape in the Democratic Republic of the Congo must stop now. Int J Gynecol Obstet 2011;114(1):1-3.

[5] Gall C. Gunmen kill Afghan women's advocate. New York Times. September 25, 2006. http://www.nytimes.com/2006/09/25/world/asia/25cnd-afghan.html. Accessed January 21, 2013.

[6] Filkins D. Afghan girls, scarred by acid, defy terror, embracing school. New York Times. January 13, 2009. http://www.nytimes.com/2009/01/14/world/asia/14kandahar.html? pagewanted=all. Accessed January 21, 2013.

[7] Murder of New York abortion doctor denounced as "terrorism". CNN website October 24, 1998. http://www.cnn.com/US/9810/24/doctor.killed.02/. Accessed January 21, 2013.

[8] Stumpe J, Davey M. Abortion doctor shot to death in Kansas church. New York Times. May 31, 2009. http://www.nytimes.com/2009/06/01/us/01tiller.html? pagewanted=all. Accessed January 21, 2013.

[9] Fam M. Cairo's litigious cleric. Wall Street Journal. October 19, 2007. http://online wsj.com/article/SB119275540781964312.html. Accessed January 21, 2013.

[10] Weber B. Manto Tshabalala-Msimang, South African who oversaw discredited AIDS policy, dies at 69. New York Times. December 16, 2009. http://www. nytimes.com/2009/12/17/world/africa/17manto.html. Accessed January 21, 2013.

[11] Potts M, Henderson C. Global warming and reproductive health. Int J Gynecol Obstet 2012;119(Suppl. 1):S64-7.

[12] Moore L. Rep. Todd Akin: The Statement and the Reaction. New York Times. August 20, 2012. http://www.nytimes.com/2012/08/21/us/politics/rep-todd-akin-legitimaterape-statement-and-reaction.html. Accessed January 13, 2013.

[13] Reuters. Indiana Republican: When life begins from rape, "God intended" it. NBC Politics. October 24, 2012. http://nbcpolitics.nbcnews.com/_news/2012/10/24 14664931-indiana-republican-when-life-begins-from-rape-god-intended-it?lite. Accessed January 13, 2013.

Timothy R.B. Johnson University of Michigan, Ann Arbor, USA E-mail address: trbj@med.umich.edu. 